$\mathrm{Nr} 3$ (66), 2020, s. 119-131

https://doi.org/10.12797/Politeja.17.2020.66.08

\author{
Monika GZIK (D) \\ Uniwersytet Łódzki \\ monika.gzik@unilodz.eu
}

\title{
DOBRE PRAKTYKI POPULARYZACJI WIEDZY O KOORDYNACJI SYSTEMÓW EMERYTALNYCH W WYBRANYCH PAŃSTWACH UNII EUROPEJSKIEJ
}

\section{REKOMENDACJE DLA POLSKI}

ABSTRACT Good Practices to Disseminate Knowledge about Coordination of Pension Systems in Selected European Union Countries. Recommendations for Poland More and more Poles are using EU regulations coordinating pension systems. These are both people who currently live in another EU country as well as people who return to Poland after working abroad. The method of analysing the literature on the subject was used and the studies on the knowledge, opinions and attitudes of Poles regarding social insurance in Poland and the coordination of pension benefits were reviewed. An analysis of current national surveys indicates that the level of this knowledge is very low. Knowledge about EU legislation functions at the expert and scientific level. The use of European experience regarding the dissemination of knowledge on the coordination of pensions seems to be necessary; therefore, selected initiatives of popularization of the knowledge in selected EU Member States were presented, thus creating recommendations for Poland.

Keywords: coordination of retirement benefits, free movement of workers in European Union, European Union, dissemination of knowledge on the coordination

Słowa kluczowe: koordynacja świadczeń emerytalnych, swobodny przepływ pracowników w Unii Europejskiej, Unia Europejska, popularyzacja wiedzy o koordynacji 


\section{WSTĘP}

Liczba migrantów na świecie wynosi obecnie $273 \mathrm{mln}$. Ponad połowa z nich mieszka w Europie $-82 \mathrm{mln}^{1}$. W $2018 \mathrm{r}$. poza granicami przebywało czasowo 2,455 $\mathrm{mln}$ stałych mieszkańców Polski, w Europie - 2,155 mln osób. Większość z nich - blisko 2,031 mln - przebywała w krajach członkowskich Unii Europejskiej (UE). Spośród państw UE w 2018 r. najwięcej polskich emigrantów było w Niemczech, Wielkiej Brytanii $^{2}$ oraz Niderlandach ${ }^{3}$. Polacy przemieszczają się bowiem wewnątrz europejskiego rynku pracy w poszukiwaniu lepszych warunków zatrudnienia i życia, wypełniając tym samym jego przestrzeń. Tę możliwość stwarza prawo swobody przepływu pracowników w UE ${ }^{4}$. Gwarancję tej swobody stanowi unijny system koordynacji emerytur 5 .

Dlaczego wiedzę o koordynacji systemów emerytalnych trzeba popularyzować? $\mathrm{Z}$ dwóch powodów. Po pierwsze, z przepisów unijnych koordynujących systemy emerytalne korzysta coraz więcej Polaków. Są to zarówno osoby obecnie mieszkające w innym państwie UE lub Islandii, Szwajcarii, Norwegii czy Liechtensteinie, jak i osoby, które po okresie pracy za granicą wracają do Polski. Chociaż dla niektórych grup pracowników kwestia emerytury jest jeszcze odległą przyszłością, a obecni emeryci najczęściej pobierają świadczenie z jednego państwa, to za kilka lat pobieranie emerytury z kilku państw członkowskich będzie znacznie częstszym zjawiskiem. Od początku lat 90. XX w. obserwujemy bowiem postępujący proces starzenia się społeczeństwa. Prognozowany udział osób w wieku 65 lat i więcej w populacji UE w 2040 r. wyniesie $20 \%$, a w 2060 r. zwiększy się do $30 \%{ }^{6}$. Po drugie, z analizy badań polskich na temat wiedzy Polaków o przysługujących im uprawnieniach wynikających z przepisów koordynacyjnych widać, iż poziom wiedzy i zrozumienia praw socjalnych pracowników migrujących w obrębie UE jest niski i wymaga poprawy w celu lepszego

1 United Nations, Department of Economic and Social Affairs, Population Division (2019). International Migration 2019: Wall Chart (ST/ESA/SER/A/431).

2 Od 1 lutego do 31 grudnia 2020 r. obowiązywać będzie tak zwany okres przejściowy, tj. czas, w którym Wielka Brytania powinna wdrożyć nowe przepisy do swego ustawodawstwa oraz podpisać deklarację o przyszłych relacjach z UE. W tym okresie UE będzie traktować Wielką Brytanię jako państwo członkowskie. Będzie obowiązywać swobodny przepływ osób, jednak rząd brytyjski nie będzie miał swoich przedstawicieli w instytucjach unijnych oraz nie będzie brał udziału w procesach decyzyjnych UE. Wielka Brytania będzie mogła zawierać nowe umowy i porozumienia, ale będą one mogły wejść w życie po zakończeniu okresu przejściowego.

3 Informacja o rozmiarach i kierunkach czasowej emigracji z Polski w latach 2004-2018, Główny Urząd Statystyczny 2019.

4 J. Barcz, M. Górka, A. Wyrozumska, Instytucje iprawo Unii Europejskiej. Podręcznik dla kierunków prawa, zarządzania i administracji, Warszawa 2017, s. 77-81.

5 Rozporządzenie Parlamentu Europejskiego i Rady (WE) nr 987/2009 z dnia 16 września 2009 r. ustanawiające procedurę wykonania rozporządzenia (WE) nr 883/2004 w sprawie koordynacji systemów zabezpieczenia społecznego, Dz.U. L 284 z 30.10.2009.

6 G. Ciura, J. Szymańczak, Starzenie się spoteczeństwa polskiego, „Infos” 2012, nr 12 (126), Biuro Analiz Sejmowych, s. 1-2. 
zagwarantowania swobody przepływu osób. W artykule przedstawiono dobre praktyki popularyzacji wiedzy w wybranych państwach UE, tworząc tym samym rekomendacje dla Polski. Wykorzystano metodę desk research, której podstawę stanowi analiza literatury, badań polskich, dokumentów statystyk publicznych, aktów prawnych. Artykuł podzielono na cztery zasadnicze części: trendy migracyjne dotyczące migracji Polaków wewnątrz europejskiego rynku pracy, istota koordynacji emerytur w UE, Polacy wobec koordynacji emerytur - wiedza, opinie i postawy w świetle badań polskich oraz dobre praktyki popularyzacji wiedzy o koordynacji emerytur w wybranych państwach członkowskich UE.

\section{POLACY WEWNĄTRZ EUROPEJSKIEGO RYNKU PRACY - TRENDY MIGRACYJNE}

Ponad połowa wszystkich migrantów na świecie mieszka w Europie, która jako kontynent stała się w okresie ostatnich kilkudziesięciu lat ważnym światowym obszarem migracji. Polacy wypełniają przestrzeń europejskiego rynku pracy, przemieszczając się w poszukiwaniu lepszych warunków życia i zatrudnienia. Przed 2004 r. legalna emigracja Polaków do Europy Zachodniej odbywała się głównie przez wyjazdy do pracy w konkretnych branżach i sektorach (rolnictwo, gastronomia) na podstawie bilateralnych umów do Niemiec, Francji, Hiszpanii, Luksemburga czy Belgii. Emigracje Polaków z powodów ekonomicznych do Wielkiej Brytanii i Irlandii zwiększyły się po przystąpieniu Polski do UE. Unijny rynek pracy dla polskich pracowników migrujących otwierał się stopniowo, rozpoczynając od Wielkiej Brytanii, Irlandii i Szwecji w 2004 r., aż do otwarcia rynków pracy przez Niemcy i Austrię w 2011 r. W końcu 2018 r. poza granicami przebywało czasowo $2,455 \mathrm{mln}$ stałych mieszkańców Polski, to jest o 85 tys. mniej niż rok wcześniej. W Europie mieszkało około 2,155 mln osób. Najwięcej polskich emigrantów przebywało w Niemczech (706 tys.), Wielkiej Brytanii (695 tys.), Niderlandach (123 tys.) oraz w Irlandii (113 tys. $)^{8}$. Obecnie emigrację zarobkową rozważa 11,8\% aktywnych lub potencjalnych uczestników rynku pracy w Polsce. Najpopularniejszym kierunkiem są Niemcy, w następnej kolejności Niderlandy oraz Wielka Brytania - do niedawna najchętniej wybierany kierunek znalazł się na trzecim miejscu zestawienia i osiągnął historycznie niski wynik. W 2018 r. odnotowano zmniejszenie się liczby stałych mieszkańców Polski przebywających w Wielkiej Brytanii. Liczba przebywających tam czasowo polskich emigrantów zmniejszyła się o około 98 tys. (12\%). Oznacza to, że więcej osób opuściło ten kraj, niż do niego wyjechało. Spośród osób, które opuściły Wielką Brytanię, część powróciła do Polski, a pozostałe osoby przeniosły się do innych państw. Niewielki wzrost liczby Polaków zaobserwowano w Niemczech, a także w Niderlandach, Austrii, Czechach, Danii, Irlandii, Szwecji, Norwegii oraz innych krajach spoza UE (głównie w Szwajcarii i Islandii). Wśród osób, których wyjazd

J. Głowiak, Zjawisko migracji - rys historyczny, „Historia i Polityka” 2012, nr 8 (15), s. 107-108.

8 Informacja o rozmiarach i kierunkach czasowej emigracji z Polski..., s. 1-4. 
za granicę został zgłoszony w jednostkach ewidencji ludności gmin, najliczniej reprezentowana w 2018 r. była grupa w wieku 30-39 lat. Natomiast 10 lat wcześniej były to osoby w wieku 20-29 lat. Można zatem przypuszczać, że znaczna część osób, które wyjechały za granicę w pierwszych latach po wstąpieniu Polski do UE, pozostała za granicą do chwili obecnej”.

Eksploracja świata przez polskich pracowników migrujących ma swoje podłoże $\mathrm{w}$ wielu czynnikach. Jeżeli przyjąć jedynie przedział czasowy przypadający na okres od przystąpienia Polski do struktur unijnych i wraz z nim stopniowego uwalniania się rynków pracy - wyraźnie uwypukla się tendencja, w której przyczynę dominującą stanowił czynnik ekonomiczny. Element ten był impulsem dla decyzji migracyjnych szczególnie wśród osób młodych, urodzonych w okresie wyżu demograficznego lat 80., dla których rodzimy rynek pracy okazał się mniej konkurencyjny niż europejski. Obecnie wśród powodów emigracji Polaków wskazuje się najczęściej na perspektywę wyższych zarobków, ale równie ważny staje się wyższy standard życia oraz czynniki socjalne, w tym emerytalne. Powodem marginalnym staje się brak pracy w Polsce ${ }^{10}$. Migracje sprzed dekady często przyjmowały krótkoterminowy charakter, oparty na fundamencie zarobkowym i edukacyjnym. W ostatnich latach rysuje się nowe zjawisko - migracji długofalowych, stałych, mających wyraźnie określony cel, w których czynnik zarobkowy znajduje się już poza podium ${ }^{11}$.

\section{ISTOTA KOORDYNACJI EMERYTUR W UNII EUROPEJSKIEJ}

Przepisy o koordynacji mają swoją długą tradycję, bowiem obowiązują już ponad 50 lat. Z jednej strony uległy one zmianie pod wpływem orzecznictwa, a z drugiej pod wplywem przekształceń w narodowych systemach zabezpieczenia społecznego ${ }^{12}$. Systemy emerytalne w państwach europejskich powstały bowiem na długo przed integracją europejską w różnych warunkach historycznych, gospodarczych, przy różnej dostępności do rynków kapitałowych oraz przy różnym podejściu do solidaryzmu społecznego ${ }^{13}$. Systemy te różnią się dość istotnie w sposobie ich finansowania czy przesłankach nabywania uprawnień. Nie istnieje zatem jeden ponadpaństwowy system emerytalny ${ }^{14}$. Podstawę prawną koordynacji systemów emerytalnych w UE stanowi Rozporządzenie Parlamentu Europejskiego i Rady (WE) nr 883/2004 z 29 kwietnia 2004 r. (rozporządzenie podstawowe)

9 Informacja o rozmiarach i kierunkach czasowej emigracji $z$ Polski...

10 Migracje zarobkowe Polaków, Raport Work Service (2019).

11 I. Chmielewska, A. Panuciak, P. Strzelecki, Polacy pracujacy za granica w 2018 r. Raport z badania, Departament Statystyki Narodowego Banku Polskiego, Warszawa 2019.

12 G. Uścińska, Zabezpieczenie spoteczne osób korzystających z prawa do przemieszczania się w Unii Europejskiej, Warszawa 2013, s. 208.

13 Z. Czepulis-Rutkowska, Trendy w funkcjonowaniu systemów emerytalnych w Europie, „Polityka Społeczna” 2016, nr 11-12, s. 2.

14 A. Szybkie, Materialnoprawny wptyw koordynacji systemów zabezpieczenia spotecznego w UE na krajowe instytucje prawne zabezpieczenia spotecznego, „Polityka Społeczna” 2017, nr 4, s. 3-20. 
oraz Rozporządzenie Parlamentu Europejskiego i Rady (WE) nr 987/2009 z 16 września 2009 r. ${ }^{15}$ Przepisy te obowiązują na terenie UE od 1 maja 2010 r., w Szwajcarii od 1 kwietnia 2012 r. oraz Islandii, Liechtensteinie i Norwegii od 1 czerwca 2012 r. ${ }^{16}$ Omawiane akty normatywne nie dążą do harmonizacji systemów ${ }^{17}$, lecz do określenia norm kolizyjnych stosowanych w przypadku konfliktów systemów narodowych w tym przedmiocie. Przepisy te mają więc na celu zapewnienie koordynacji między krajowymi ustawodawstwami zabezpieczenia społecznego, z których każde odrębnie określa warunki objęcia ochroną i przystąpienia (afiliacji) do określonego systemu zabezpieczenia społecznego, łącznie z warunkami, w których obowiązek ochrony lub pozostawania w systemie ustaje. Zakres przedmiotowy komentowanych rozporządzeń nie obejmuje warunków powstania obowiązku ubezpieczenia czy też jego ustania.

$\mathrm{Z}$ unijnej koordynacji w zakresie emerytur korzystają obywatele państw członkowskich UE (w tym obywatele polscy) oraz uchodźcy i bezpaństwowcy mieszkający na terytorium jednego z państw członkowskich, a także obywatele państw trzecich, jeśli mieszkają na terytorium któregoś państwa członkowskiego ${ }^{18}$. Przepisy dotyczące koordynacji dotyczą osób wykonujących aktywność zawodową jako pracownicy, pracujący na podstawie umów cywilnoprawnych, prowadzący działalność na własny rachunek bądź na podstawie innych tytułów do ubezpieczeń społecznych. Koordynacją objęte są wylącznie osoby znajdujące się w tzw. sytuacji unijnej, czyli dotyczącej co najmniej dwóch państw członkowskich - które pracowały w dwóch państwach członkowskich albo pracowały $\mathrm{w}$ jednym państwie członkowskim, a zamieszkują w innym państwie członkowskim. Obywatel Turcji, zamieszkały i pracujący w Polsce, który przed przyjazdem do Polski pracował również w Niemczech, może skorzystać z unijnej koordynacji systemów zabezpieczenia społecznego w zakresie ustalania uprawnień do świadczeń emerytalnych poprzez zsumowanie okresów ubezpieczenia w obu państwach członkowskich. W sytuacji, gdy osoba zainteresowana uzyskaniem prawa do emerytury w jednym państwie członkowskim nie posiada okresu ubezpieczenia (zamieszkania) wymaganego do uzyskania tego świadczenia, to - dla przyznania emerytury - uwzględnia się (dolicza, sumuje) również zagraniczne okresy ubezpieczenia (zamieszkania) tej osoby z wszystkich innych państw członkowskich, jeśli nie pokrywają się one z polskimi okresami ubezpieczenia ${ }^{19}$. Osoba ubezpieczona w więcej niż jednym państwie członkowskim

15 Rozporządzenie Parlamentu Europejskiego i Rady (WE) nr 987/2009 z dnia 16 września 2009 r. ustanawiające procedurę wykonania rozporządzenia (WE) nr 883/2004 w sprawie koordynacji systemów zabezpieczenia społecznego, Dz.U. L 284 z 30.10.2009.

16 K. Ślebzak, Koordynacja systemów zabezpieczenia spotecznego. Komentarz, Warszawa 2012, s. 41-43.

17 M. Kurzynoga, Gwarancje swobodnego przeptywu pracowników, [w:] Prawo Unii Europejskiej. Instytucje i porzadek prawny. Prawo materialne, red. A. Zawidzka-Łojek, R. Grzeszczak, A. Łazowski, Instytut Wydawniczy EuroPrawo, Warszawa 2015, s. 471-472.

18 B. Owsiak, Popularyzowanie wiedzy o ubezpieczeniach spotecznych przez Zaktad Ubezpieczeń Spotecznych, „Ubezpieczenia Społeczne. Teoria i Praktyka” 2017, nr 1 (132), s. 79-137.

19 A. Szybkie, Na czym polega unijna koordynacja. Korzyści emerytalno-rentowe dla osób migrujących wynikające z cztonkostwa Polski w Unii Europejskiej. 15 lat Unii bez granic dla ubezpieczonych, ZUS, Warszawa 2019, s. 10-12. 
UE składa wniosek o emeryturę w instytucji jednego państwa członkowskiego. Wniosek ten w sposób automatyczny uruchamia rozpatrywanie uprawnień do świadczenia w tych państwach członkowskich, w których osoba była ubezpieczona. Ponadto wniosek można złożyć za pośrednictwem instytucji ubezpieczeniowej państwa zamieszkania, która przekaże go do instytucji właściwej. Wszystkich formalności można więc dokonać w państwie zamieszkania. Instytucja ubezpieczeniowa tego kraju przyjmie wniosek emerytalny, skompletuje go i przekaże do instytucji ubezpieczeniowych wszystkich państw, w których zainteresowany był ubezpieczony. To istotne ułatwienie proceduralne. Ta sama instytucja przekazuje zbiorcze zestawienie decyzji (dokument P1) ${ }^{20} \mathrm{w}$ tym języku urzędowym UE, o który zawnioskowano. Przepisy UE dotyczące koordynacji emerytur niosą ze sobą szereg korzyści. Analizowane rozporządzenie unijne przewiduje zasadę transferu świadczeń. Oznacza ona, iż osoba, której przyznano emeryturę, może ją odbierać na rachunek bankowy w państwie zamieszkania, nawet jeśli jest ona wypłacana przez instytucję zagraniczną, na przykład osoba, która mieszka w Polsce, może otrzymywać austriacką emeryturę na polskie konto bankowe ${ }^{21}$.

\section{POLACY WOBEC KOORDYNACJI EMERYTUR - WIEDZA, OPINIE I POSTAWY W ŚWIETLE BADAŃ POLSKICH}

W artykule dokonano przeglądu badań polskich w zakresie wiedzy, opinii i postaw Polaków wobec systemu ubezpieczeń społecznych i jego międzynarodowych aspektów (tabela 1). Ich analiza wskazuje, iż brak jest badań dotyczących wiedzy, postaw i opinii na temat koordynacji emerytur, mimo iż Zakład Ubezpieczeń Społecznych (ZUS) w swojej 80-letniej historii od niemal dwudziestu lat zajmuje się ustawodawstwem UE w zakresie ubezpieczeń społecznych i jego wdrażaniem do polskiego porządku prawne$\mathrm{go}^{22}$. Nadal badacze skupiają się głównie na polskim systemie ubezpieczeń społecznych, pomijając jego międzynarodowy aspekt.

Tabela 1. Wiedza, opinie i postawy Polaków wobec koordynacji emerytur - przegląd badań polskich

\begin{tabular}{|c|c|c|}
\hline Autor & $\begin{array}{c}\text { Okres } \\
\text { badania }\end{array}$ & \multicolumn{1}{|c|}{ Wnioski } \\
\hline $\begin{array}{c}\text { J. Czapiński } \\
\text { T. Panek }\end{array}$ & $\begin{array}{l}\text { Katalog badań dotyczących stanu świadomości obywatelskiej w } \\
\text { zakresie ryzyk socjalnych i zaufania do systemu ubezpieczeń spo- } \\
\text { tecznych za każdym razem dowodzi, że polskie społeczeństwo } \\
\text { nie rozumie jego istoty. }\end{array}$ \\
\hline
\end{tabular}

20 Formularz P1 to dokument (przenośny), który podsumowuje wszystkie decyzje dotyczące świadczeń z tytułu inwalidztwa, starości lub renty rodzinnej podejmowane przez instytucje europejskie odpowiedzialne za ubezpieczenie emerytalne.

21 A. Szybkie, Materialnoprawny wptyw..., s. 1-12.

22 E. Borowczyk, Upowszechnianie wiedzy o ustawodawstwie Unii Europejskiej w zakresie ubezpieczeń spotecznych, [w:] Upowszechnianie wiedzy i edukacja w zakresie ubezpieczeń spotecznych, ZUS, Kraków 2013, s. 83. 


\begin{tabular}{|c|c|c|}
\hline Autor & $\begin{array}{l}\text { Okres } \\
\text { badania }\end{array}$ & Wnioski \\
\hline $\begin{array}{l}\text { A. Sobczyk } \\
\text { Ł. T. Sroka } \\
\text { J. Frańczak } \\
\text { A. Chłoń- } \\
\text {-Domińczak } \\
\text { E. Borowczyk } \\
\text { K. Ostrowska } \\
\text { M. Benio }\end{array}$ & 2013 & $\begin{array}{l}\text { Stan wiedzy o ubezpieczeniach społecznych w Polsce jest alar- } \\
\text { mujący. Kryzys edukacji w zakresie ubezpieczeń społecznych na } \\
\text { studiach prawniczych i w szkołach. Niedostosowanie progra- } \\
\text { mów nauczania i podręczników marginalizujących problematy- } \\
\text { kę ubezpieczeniową. }\end{array}$ \\
\hline W. Sułkowska & 2013 & $\begin{array}{l}\text { Świadomość społeczna w obszarze ubezpieczeń społecznych - } \\
\text { świadomi obywatele powinni podejmować działania o charakte- } \\
\text { rze prewencyjno-zabezpieczającym. }\end{array}$ \\
\hline R. Marczak & 2016 & $\begin{array}{l}\text { Poziom wiedzy Polaków na temat koordynacji systemów zabez- } \\
\text { pieczenia społecznego jest bardzo niski i nie odbiega od ogól- } \\
\text { nie niskiego poziomu wiedzy o ubezpieczeniach społecznych } \\
\text { w Polsce. }\end{array}$ \\
\hline M. Łebkowska & 2017 & $\begin{array}{l}\text { Rola państwa w edukowaniu o ubezpieczeniach. Negatywna } \\
\text { ocena podstawy programowej szkół ponadgimnazjalnych, któ- } \\
\text { ra ubezpieczeniom poświęca kilka godzin lekcyjnych, a między } \\
\text { ubezpieczeniami społecznymi i gospodarczymi nie stawia wyraź- } \\
\text { nej linii podziału. Edukacja ubezpieczeniowa zajmuje niewiele } \\
\text { miejsca w treściach nauczania, a przekazywana wiedza nie jest } \\
\text { precyzyjna. }\end{array}$ \\
\hline $\begin{array}{l}\text { T. Lasocki } \\
\text { D. Bożek }\end{array}$ & 2017 & $\begin{array}{l}\text { Problem nauczania w zakresie ubezpieczeń społecznych na wy- } \\
\text { działach polskich uczelni wyższych. Niewielki zasięg wykładów, } \\
\text { małe zainteresowanie zarówno studentów, jak i samych uczelni. }\end{array}$ \\
\hline M. Mrozowski & 2017 & $\begin{array}{l}\text { ZUS nie cieszy się wysokim zaufaniem społeczeństwa. } \\
\text { Negatywny wizerunek ZUS współtworzą media, prasa i portale } \\
\text { internetowe. }\end{array}$ \\
\hline D. Owczarek & 2017 & $\begin{array}{l}\text { Poziom wiedzy wobec ubezpieczeń społecznych jest niski, a po- } \\
\text { stawy Polaków - negatywne. Niski poziom wiedzy, a wyrazista } \\
\text { (negatywna) postawa Polaków wobec ubezpieczeń społecznych i } \\
\text { Zakładu Ubezpieczeń Społecznych. }\end{array}$ \\
\hline T. Szumlicz & 2017 & $\begin{array}{l}\text { Istotnym problemem w uświadamianiu i zrozumieniu zasad spo- } \\
\text { łecznej przezorności ubezpieczeniowej jest odpowiednia eduka- } \\
\text { cja. Jej przekaźnikiem są m.in. media oraz państwo. }\end{array}$ \\
\hline A. Szybkie & 2017 & $\begin{array}{l}\text { Potrzeba edukowania społeczeństwa w zakresie koordynacji za- } \\
\text { bezpieczeń społecznych. }\end{array}$ \\
\hline
\end{tabular}

Źródło: opracowanie własne na podstawie publikacji podanych w przypisie $^{23}$.

23 M. Benio, Spoteczny odbiór ubezpieczeń spotecznych - od obalania mitów po rzetelna informacje, [w:] Upowszechnianie wiedzy i edukacja w zakresie ubezpieczeń spotecznych, ZUS, Kraków 2013; E. Borowczyk, Upowszechnianie wiedzy o ustawodawstwie Unii Europejskiej w zakresie ubezpieczeń spotecznych, [w:] Upowszechnianie wiedzy i edukacja w zakresie ubezpieczeń spotecznych, ZUS, Kraków 2013; A. Chłon-Domińczak, Upowszechnianie wiedzy o ubezpieczeniach spotecznych - doświadczenia 
Janusz Czapiński i Tomasz Panek w latach 2000-2015 przeprowadzili cykl badań dotyczący stanu świadomości obywatelskiej w zakresie ryzyk socjalnych i zaufania do systemu ubezpieczeń społecznych, za każdym razem dowodząc, że polskie społeczeństwo nie rozumie jego istoty. Badania prowadzone przez Roberta Marczaka ukazują niski poziom wiedzy Polaków na temat koordynacji systemów zabezpieczenia społecznego. Nie odbiega on od ogólnie niskiego poziomu wiedzy o ubezpieczeniach społecznych w Polsce. Z badań przeprowadzonych przez Monikę Łebkowską wynika, iż edukacja ubezpieczeniowa zajmuje niewiele miejsca w treściach nauczania. Analiza badań Tomasza Lasockiego i Diany R. Bożek pozwala wnioskować, iż istnieje problem nauczania w zakresie ubezpieczeń społecznych na wydziałach polskich uczelni wyższych (niewielki zasięg wykładów, małe zainteresowanie zarówno studentów, jak i uczelni). Ewa Borowczyk podkreśla, iż wiedza o ustawodawstwie UE w zakresie ubezpieczeń społecznych funkcjonuje na poziomie ekspercko-naukowym i urzędniczo-administracyjnym ${ }^{24}$. Dominik Owczarek wskazuje, iż postawy Polaków wobec ubezpieczeń społecznych są negatywne. Maciej Mrozowski w swoich badaniach wykazuje, że ZUS nie cieszy się wysokim zaufaniem społecznym. Badania na temat świadomości społecznej w obszarze ubezpieczeń społecznych prowadzą głównie przedstawiciele ZUS. Jednakże rozpowszechnianie wiedzy na temat ubezpieczeń społecznych wpisuje się w obowiązek ustawowy. Ustawa o systemie ubezpieczeń społecznych zobowiązuje ZUS do prowadzenia działań popularyzujących wiedzę

międzynarodowe, [w:] Upowszechnianie wiedzy i edukacja w zakresie ubezpieczeń spotecznych, ZUS, Kraków 2013; K. Ostrowska, Udziat mediów w procesie edukacji spotecznej w zakresie ubezpieczeń spotecznych, [w:] Upowszechnianie wiedzy i edukacja w zakresie ubezpieczeń spotecznych, ZUS, Kraków 2013; J. Frańczak, Wptyw orzecznictwa Sądu Najwyższego na stosowanie i upowszechnianie prawa ubezpieczeń spotecznych, [w:] Upowszechnianie wiedzy i edukacja w zakresie ubezpieczeń spotecznych, ZUS, Kraków 2013; A. Sobczyk, $W$ sprawie kryzysu edukacji z zakresu ubezpieczeń spotecznych na studiach prawniczych, [w:] Upowszechnianie wiedzy i edukacja w zakresie ubezpieczeń spotecznych, ZUS, Kraków 2013; Ł. T. Sroka, Edukacja na temat ubezpieczeń spotecznych w kontekście naukowo-dydaktycznej dziatalności Uniwersytetu Pedagogicznego w Krakowie - stan obecny i program dziatania, [w:] Upowszechnianie wiedzy i edukacja w zakresie ubezpieczeń spotecznych, ZUS, Kraków 2013; J. Czapiński, T. Panek, Diagnoza spoteczna 2013. Warunki i jakość życia Polaków. Raport Departamentu Analiz Ekonomicznych i Prognoz, Warszawa 2014; R. Marczak, Wiedza i postawy wobec ubezpieczeń spotecznych. Raport z badań, ZUS, Warszawa 2016; T. Lasocki, D. Bożek, Ubezpieczenia spoteczne w ofercie dydaktycznej wydziatów prawa uczelni wyższych, „Ubezpieczenia Społeczne. Teoria i Praktyka” 2017, nr 1 (123); M. Łebkowska, Edukacja ubezpieczeniowa mtodzieży ponadgimnazjalnej w systemie szkolnym i poza nim, „Ubezpieczenia Społeczne. Teoria i Praktyka” 2017, nr 1 (123); M. Mrozowski, Zaktad Ubezpieczeń Spotecznych w mediach, media o ZUS. Ksztattowanie wizerunku instytucji i wiedzy o systemie ubezpieczeń spotecznych, „Ubezpieczenia Społeczne. Teoria i Praktyka” 2017, nr 1 (132); D. Owczarek, Niski poziom wiedzy a wyrazista postawa Polaków wobec ubezpieczeń spotecznych i Zaktadu Ubezpieczeń Spotecznych, „Ubezpieczenia Społeczne. Teoria i Praktyka” 2017, nr 1 (123); B. Owsiak, Popularyzowanie wiedzy o ubezpieczeniach spotecznych przez Zaktad Ubezpieczeń Spotecznych, „Ubezpieczenia Społeczne. Teoria i Praktyka” 2017, nr 1 (132); T. Szumlicz, Świadomość ryzyka społecznego jako podstawa wiedzy o systemie ubezpieczeń spotecznych, „Ubezpieczenia Społeczne. Teoria i Praktyka” 2017, nr 1 (123); A. Szybkie, Popularyzowanie wiedzy o koordynacji systemów zabezpieczenia spotecznego, „Ubezpieczenia Społeczne. Teoria i Praktyka” 2017, nr 1 (132). 
o ubezpieczeniach społecznych ${ }^{25}$. Ustawodawca nie doprecyzował jednak zakresu i formy tej popularyzacji ${ }^{26}$.

\section{DOBRE PRAKTYKI POPULARYZACJI WIEDZY O KOORDYNACJI EMERYTUR W WYBRANYCH PAŃSTWACH CZŁONKOWSKICH UNII EUROPEJSKIEJ}

W wielu państwach europejskich wiedza na temat koordynacji emerytur i wynikających z niej prawach jest szeroko upowszechniana przez krajowe instytucje właściwe do spraw zabezpieczenia społecznego. Wiedza ta przekazywana jest odbiorcom w sposób uporządkowany i przystępny. W tabeli 2 przedstawiono wybrane krajowe inicjatywy w Austrii, Belgii, Bułgarii, Danii, Hiszpanii, Irlandii i Niemczech.

Tabela 2. Sposoby popularyzacji wiedzy o koordynacji emerytur w wybranych państwach członkowskich UE

\begin{tabular}{|c|c|c|}
\hline $\begin{array}{c}\text { Państwo } \\
\text { członkowskie }\end{array}$ & Dobre praktyki w UE & Polskie praktyki na tle UE \\
\hline Austria & $\begin{array}{l}\text { elektroniczny biuletyn (newsletter), sku- } \\
\text { piający się w swej treści między innymi na } \\
\text { unijnej koordynacji emerytur }\end{array}$ & brak podobnych inicjatyw \\
\hline Belgia & $\begin{array}{l}\text { projekt Full Social Jacket (2013) - serwis } \\
\text { internetowy, zawierający informacje na te- } \\
\text { mat wszystkich aspektów zabezpieczenia } \\
\text { społecznego w tym państwie jako inicja- } \\
\text { tywa Federalnej Służby Zabezpieczenia } \\
\text { Społecznego: cykl filmów przedstawiają- } \\
\text { cych osobiste historie migrujących oby- } \\
\text { wateli tego kraju oraz wywiady eksperckie } \\
\text { dotyczące między innymi praw i obowiąz- } \\
\text { ków wynikających z rozporządzenia unij- } \\
\text { nego oraz strona internetowa przeznaczo- } \\
\text { na dla osób, które chcą osiedlić się w Belgii } \\
\text { lub podjąć tam pracę (dostępny w czterech } \\
\text { językach: angielskim, holenderskim, nie- } \\
\text { mieckim i francuskim) }\end{array}$ & brak podobnych inicjatyw \\
\hline Butgaria & $\begin{array}{l}\text { szkolenia w zakresie koordynacji emery- } \\
\text { tur dla studentów z różnych instytutów } \\
\text { w Bułgarii }\end{array}$ & brak podobnych inicjatyw \\
\hline Dania & $\begin{array}{l}\text { szkolenia w zakresie ustalania właściwe- } \\
\text { go ustawodawstwa skierowane głównie do } \\
\text { przedstawicieli firm }\end{array}$ & brak podobnych inicjatyw \\
\hline
\end{tabular}

25 Ustawa o systemie ubezpieczeń spotecznych z 13 października 1998 roku, Dz.U. nr 137, poz. 887.

26 B. Gudowska, J. Strusińska-Żukowska, Ustawa o systemie ubezpieczeń spotecznych. Komentarz, Warszawa 2014, s. 704 . 


\begin{tabular}{|c|c|c|}
\hline $\begin{array}{c}\text { Państwo } \\
\text { członkowskie }\end{array}$ & Dobre praktyki w UE & Polskie praktyki na tle UE \\
\hline Hiszpania & $\begin{array}{l}\text { strona internetowa (www.sepe.es) - prze- } \\
\text { wodniki dla osób, które podejmują za- } \\
\text { trudnienie w Hiszpanii oraz pracują bądź } \\
\text { chciałyby pracować w innych państwach } \\
\text { UE; portal skierowany do hiszpańskich } \\
\text { obywateli, którzy planują powrót do kra- } \\
\text { ju; materiały dotyczące koordynacji dla } \\
\text { osób, które chcą wyjechać do innego kraju } \\
\text { członkowskiego }\end{array}$ & $\begin{array}{l}\text { strona internetowa ZUS (www.zus.pl) } \\
\text { - nie zawiera praktycznych przewodni- } \\
\text { ków dla Polaków podejmujących pracę } \\
\text { w innych państwach członkowskich }\end{array}$ \\
\hline Irlandia & $\begin{array}{l}\text { strona internetowa (www.welfare.ie) do- } \\
\text { stępna również w języku polskim (infor- } \\
\text { macje na temat warunków, które trzeba } \\
\text { spełnić, aby otrzymywać świadczenia wy- } \\
\text { jeżdżając do pracy do innego kraju lub } \\
\text { ubiegać się o świadczenia emerytalne w } \\
\text { Irlandii }\end{array}$ & $\begin{array}{l}\text { strona internetowa ZUS (www.zus. } \\
\text { pl) - nie zawiera praktycznych wska- } \\
\text { zówek na temat warunków, które trze- } \\
\text { ba spełnić, aby otrzymać świadczenie } \\
\text { emerytalne wyjeżdżając do pracy do } \\
\text { innego państwa członkowskiego, brak } \\
\text { jest również przekierowania na stronę } \\
\text { instytucji zabezpieczenia społecznego } \\
\text { w określonym państwie }\end{array}$ \\
\hline Niemcy & $\begin{array}{l}\text { inicjatywa Transwel - współpraca europej- } \\
\text { skich uniwersytetów w zakresie koordynacji; } \\
\text { projekt badawczy prowadzony w następują- } \\
\text { cych państwach (parach): Bułgaria-Niemcy, } \\
\text { Węgry-Austria, Estonia-Szwecja oraz } \\
\text { Polska - Wielka Brytania (w projekcie sku- } \\
\text { piono się na badaniu migracji obywateli i ich } \\
\text { praw socjalnych) }\end{array}$ & $\begin{array}{l}\text { problem nauczania w zakresie ubez- } \\
\text { pieczeń społecznych na wydziałach } \\
\text { polskich uczelni wyższych - niewielki } \\
\text { zasięg wykładów, małe zainteresowa- } \\
\text { nie zarówno studentów, jak i samych } \\
\text { uczelni }\end{array}$ \\
\hline
\end{tabular}

Źródło: opracowanie własne na podstawie: www.fullsocialjacket.org/, www.welfare.ie, www.sepe.es, www. transwel.org (19V V2019); A. Szybkie, Popularyzowanie wiedzy o koordynacji systemów zabezpieczenia spotecznego, „Ubezpieczenia Społeczne. Teoria i Praktyka” 2017, nr 1 (132), s. 1-12.

Niemieckie instytucje zabezpieczenia społecznego uczestniczą w interdyscyplinarnej inicjatywie Transwel, opierającej się na współpracy europejskich uniwersytetów w zakresie koordynacji. Jest to projekt badawczy prowadzony w następujących państwach (parach): Bułgaria-Niemcy, Węgry-Austria, Estonia-Szwecja oraz Polska Wielka Brytania. W projekcie skupiono się również na badaniu migracji obywateli i ich praw socjalnych. W Belgii zrealizowano projekt Full Social Jacket. Serwis internetowy zawierający informacje na temat wszystkich aspektów zabezpieczenia społecznego w tym państwie powstał w 2013 r. z inicjatywy Federalnej Służby Zabezpieczenia Społecznego. Autorzy projektu w celu zwiększenia świadomości ubezpieczeniowej swoich obywateli posłużyli się metaforą kurtki spotecznej oraz dziesięcioma filmami przedstawiającymi wywiady eksperckie i historie osobiste pracowników migrujących, czyniąc tym samym problematykę ubezpieczeniową bardziej przystępną dla odbiorcy. Austriackie instytucje łącznikowe przygotowują foldery i raporty oraz rozsyłają elektroniczny biuletyn (newsletter) skupiający się w swej treści na unijnej koordynacji 
systemów zabezpieczenia społecznego. Bułgarskie instytucje zabezpieczenia społecznego prowadzą szkolenia w zakresie koordynacji emerytur dla studentów z różnych instytutów w Bułgarii. W Irlandii powstała strona internetowa dostępna również w języku polskim, zawierająca informacje na temat warunków, które trzeba spełnić, aby otrzymywać świadczenia wyjeżdżając do pracy do innego kraju lub ubiegać się o świadczenia emerytalne w tym państwie. Instytucje ubezpieczeniowe w Danii szkolą przedstawicieli przedsiębiorstw w zakresie ustalania właściwego ustawodawstwa. W Hiszpanii wydawany jest przewodnik dla osób, które podejmują tam zatrudnienie w oraz pracują w państwach członkowskich, a także portal internetowy skierowany do hiszpańskich obywateli, którzy planują powrót do kraju. W Polsce brakuje podobnych inicjatyw.

\section{PODSUMOWANIE}

Polscy pracownicy migrujący wypełniają przestrzeń europejskiego rynku pracy. Tę możliwość stwarza im unijny system koordynacji systemów zabezpieczenia społecznego. $\mathrm{Z}$ przepisów unijnych koordynujących systemy emerytalne korzysta coraz więcej Polaków. Są to zarówno osoby obecnie mieszkające w innym państwie UE lub Islandii, Szwajcarii, Norwegii czy Liechtensteinie oraz ci, którzy po okresie pracy za granicą wracają do Polski. Za kilka lat pobieranie emerytury z kilku państw członkowskich będzie znacznie częstszym zjawiskiem. Pomimo praktycznej doniosłości unijnych przepisów o koordynacji systemów emerytalnych dla polskich pracowników migrujących wewnątrz europejskiego rynku pracy, poziom wiedzy Polaków o prawach wynikających z tych rozporządzeń jest niski, czego dowodzi przeprowadzony przez autorkę przegląd badań polskich. Doświadczenia innych państw członkowskich w zakresie upowszechniania wiedzy na temat koordynacji emerytur stanowią rekomendacje dla Polski, gdzie brakuje podobnych inicjatyw. Wiedza, która może mieć wpływ na większe zainteresowanie zabezpieczeniem finansowym na starość, przezorność ubezpieczeniową Polaków dotyczącą wyboru państwa pracy, warunków pracy i płacy, wysokości odprowadzanych składek ubezpieczeniowych czy korzystania z dodatkowych świadczeń ubezpieczeniowych, funkcjonuje głównie na poziomie ekspercko-naukowym oraz urzędniczo-administracyjnym.

\section{BIBLIOGRAFIA}

Barcz J., Górka M., Wyrozumska A., Instytucje i prawo Unii Europejskiej. Podręcznik dla kierunków prawa, zarządzania i administracji, Warszawa 2017.

Benio M., Spoteczny odbiór ubezpieczeń spotecznych - od obalania mitów po rzetelna informacje, [w:] Upowszechnianie wiedzy i edukacja w zakresie ubezpieczeńspotecznych, red. T. Nawrocka-Szczerbik, Kraków 2013.

Borowczyk E., Upowszechnianie wiedzy o ustawodawstwie Unii Europejskiej w zakresie ubezpieczeń spotecznych, [w:] Upowszechnianie wiedzy i edukacja w zakresie ubezpieczeń spotecznych, ZUS, Kraków 2013. 
Chłon-Domińczak A., Upowszechnianie wiedzy o ubezpieczeniach spotecznych - doświadczenia międzynarodowe, [w:] Upowszechnianie wiedzy i edukacja w zakresie ubezpieczeń spotecznych, ZUS, Kraków 2013.

Chmielewska I., Panuciak A., Strzelecki P., Polacy pracujacy za granica w 2018 r. Raport z badania, Departament Statystyki Narodowego Banku Polskiego, Warszawa 2019.

Ciura G., Szymańczak J., Starzenie się spoteczeństwa polskiego, „Infos” 2012, nr 12(126), Biuro Analiz Sejmowych.

Czapiński J., Panek T., Diagnoza spoteczna 2013. Warunki i jakość życia Polaków. Raport, Departament Analiz Ekonomicznych i Prognoz (Ministerstwo Pracy i Polityki Społecznej), Warszawa 2014.

Frańczak J., Wptyw orzecznictwa Sądu Najwyższego na stosowanie i upowszechnianie prawa ubezpieczeń spotecznych, [w:] Upowszechnianie wiedzy i edukacja w zakresie ubezpieczeń spotecznych, ZUS, Kraków 2013.

Głowiak J., Zjawisko migracji - rys historyczny, „Historia i Polityka” 2012, nr 8 (15), http:// dx.doi.org/10.12775/HiP.2012.019.

Główny Urząd Statystyczny, Informacja o rozmiarach i kierunkach czasowej migracji z Polski w latach 2004-2016, Departament Badań Demograficznych i Rynku Pracy, Warszawa 2019.

Gudowska B., Strusińska-Żukowska J., Ustawa o systemie ubezpieczeń spotecznych. Komentarz, Warszawa 2014.

Kurzynoga M., Gwarancje swobodnego przeptywu pracowników, [w:] Prawo Unii Europejskiej. Instytucje i porządek prawny. Prawo materialne, red. A. Zawidzka-Łojek, R. Grzeszczak, A. Łazowski, Warszawa 2015.

Lasocki T., Bożek D., Ubezpieczenia spoteczne w ofercie dydaktycznej wydziatów prawa uczelni wyższych, „Ubezpieczenia Społeczne. Teoria i Praktyka” 2017, nr 1 (132).

Łebkowska M., Edukacja ubezpieczeniowa mtodzieży ponadgimnazjalnej w systemie szkolnym i poza nim, „Ubezpieczenia Społeczne. Teoria i Praktyka” 2017, nr 1 (132).

Marczak R., Wiedza i postawy wobec ubezpieczeń spotecznych. Raport z badań, ZUS, Warszawa 2016.

Migracje zarobkowe Polaków, Raport Work Service (2019).

Mrozowski M., Zaktad Ubezpieczeń Spotecznych w mediach, media o ZUS. Ksztattowanie wizerunku instytucji i wiedzy o systemie ubezpieczeń spotecznych, „Ubezpieczenia Społeczne. Teoria i Praktyka” 2017, nr 1 (132).

Ostrowska K., Udziat mediów w procesie edukacji spotecznej $w$ zakresie ubezpieczeń spotecznych, [w:] Upowszechnianie wiedzy i edukacja w zakresie ubezpieczeń spotecznych, ZUS, Kraków 2013.

Owczarek D., Niski poziom wiedzy a wyrazista postawa Polaków wobec ubezpieczeń spotecznych i Zaktadu Ubezpieczeń Spotecznych, „Ubezpieczenia Społeczne. Teoria i Praktyka” 2017, nr 1 (132).

Owsiak B., Popularyzowanie wiedzy o ubezpieczeniach spotecznych przez Zaktad Ubezpieczeń Spotecznych, „Ubezpieczenia Społeczne. Teoria i Praktyka” 2017, nr 1 (132).

Rozporządzenie Parlamentu Europejskiego i Rady (WE) nr 987/2009 z dnia 16 września 2009 r. ustanawiające procedurę wykonania rozporządzenia (WE) nr 883/2004 w sprawie koordynacji systemów zabezpieczenia społecznego, Dz.U. L 284 z 30.10.2009. 
Sobczyk A., W sprawie kryzysu edukacji z zakresu ubezpieczeń spotecznych na studiach prawniczych, [w:] Upowszechnianie wiedzy i edukacja w zakresie ubezpieczeń spotecznych, ZUS, Kraków 2013.

Sroka Ł.T., Edukacja na temat ubezpieczeń spotecznych w kontekście naukowo-dydaktycznej dziatalności Uniwersytetu Pedagogicznego w Krakowie - stan obecny i program dziatania, [w:] Upowszechnianie wiedzy i edukacja w zakresie ubezpieczeń spotecznych, ZUS, Kraków 2013.

Szumlicz T., Świadomość ryzyka społecznego jako podstawa wiedzy o systemie ubezpieczeń społecznych, „Ubezpieczenia Społeczne. Teoria i Praktyka” 2017, nr 1 (132).

Szybkie A., Materialnoprawny wptyw koordynacji systemów zabezpieczenia spotecznego w UE na krajowe instytucje prawne zabezpieczenia spotecznego, „Polityka Społeczna” 2017, nr 4.

Szybkie A., Na czym polega unijna koordynacja. Korzyści emerytalno-rentowe dla osób migrujacych wynikajace z cztonkostwa Polski w Unii Europejskiej. 15 lat Unii bez granic dla ubezpieczonych, ZUS, Warszawa 2019.

Szybkie A., Popularyzowanie wiedzy o koordynacji systemów zabezpieczenia spotecznego, „Ubezpieczenia Społeczne. Teoria i Praktyka” 2017, nr 1 (132).

Ślebzak K., Koordynacja systemów zabezpieczenia spotecznego. Komentarz, Warszawa 2012.

United Nations, Department of Economic and Social Affairs, Population Division (2019). International Migration 2019: Wall Chart (ST/ESA/SER/A/431).

Ustawa z dnia 13 października 1998 r. o systemie ubezpieczeń społecznych, Dz.U. nr 137, poz. 887.

Uścińska G., Zabezpieczenie spoteczne osób korzystajacych z prawa do przemieszczania się w Unii Europejskiej, Warszawa 2013.

www.fullsocialjacket.org.

www.sepe.es.

www.transwel.org.

www.welfare.ie.

Monika GZIK - absolwentka Wydziału Prawa i Administracji Uniwersytetu Łódzkiego. Doktorantka w Katedrze Pracy i Polityki Społecznej Uniwersytetu Łódzkiego. Jej zainteresowania naukowe oscylują wokół europejskiego rynku pracy oraz koordynacji systemów zabezpieczenia społecznego w Unii Europejskiej. 